\title{
Multitemporal L-and C-Band Synthetic Aperture Radar To Highlight Differences in Water Status Among Boreal Forest and Wetland Systems in the Yukon Flats, Interior Alaska
}

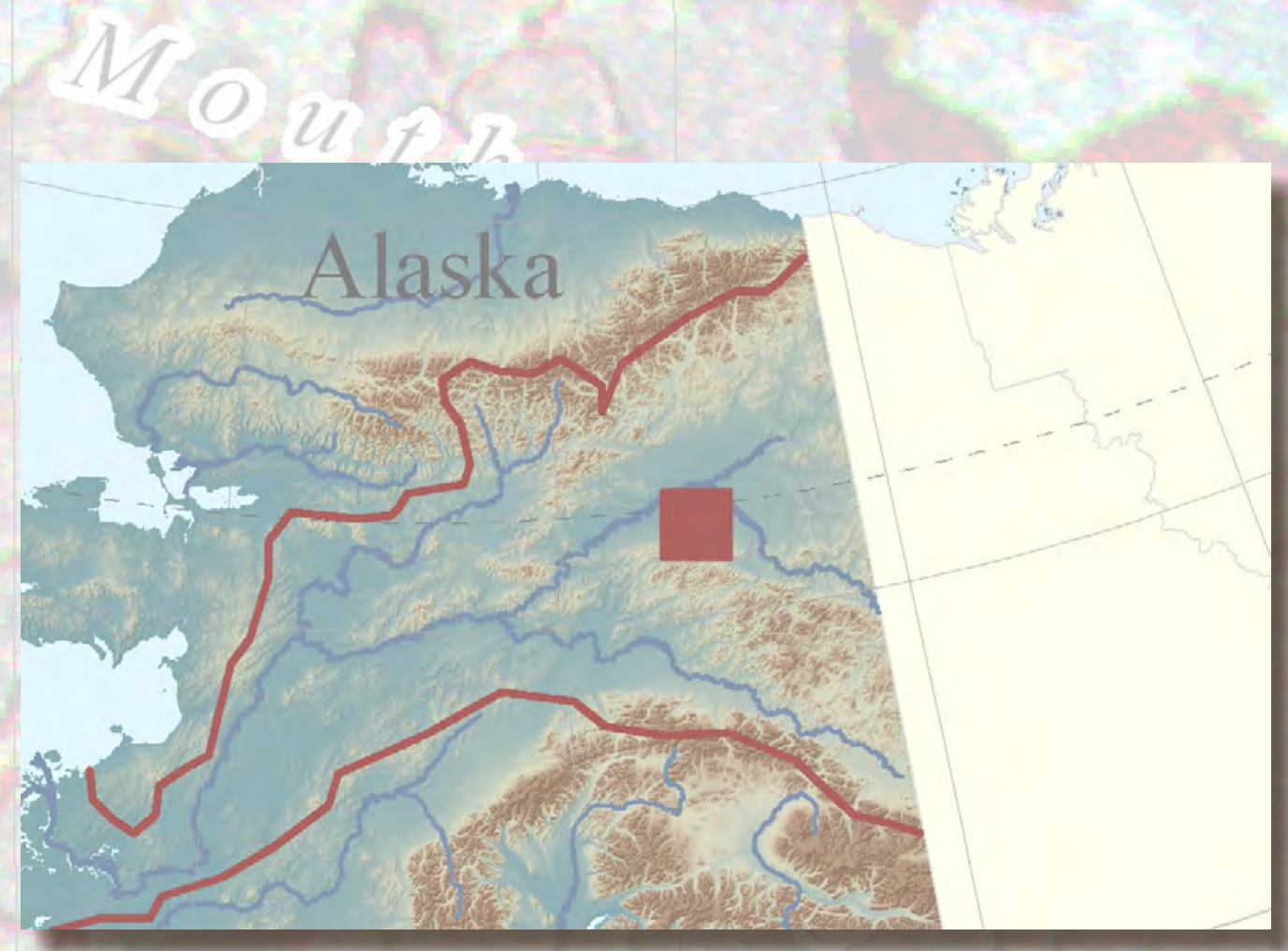

Open-File Report 2010-1027 



\section{Multitemporal L-and C-Band Synthetic Aperture Radar To Highlight Differences in Water Status Among Boreal Forest and Wetland Systems in the Yukon Flats, Interior Alaska}

By Andrew W. Balser and Bruce K. Wylie

Open-File Report 2010-1027 


\section{U.S. Department of the Interior \\ KEN SALAZAR, Secretary \\ U.S. Geological Survey \\ Marcia K. McNutt, Director}

U.S. Geological Survey, Reston, Virginia: 2010

This and other USGS information products are available at http://store.usgs.gov/
U.S. Geological Survey
Box 25286, Denver Federal Center
Denver, CO 80225
To learn about the USGS and its information products visit http://www.usgs.gov/
1-888-ASK-USGS

Any use of trade, product, or firm names is for descriptive purposes only and does not imply endorsement by the U.S. Government.

Although this report is in the public domain, permission must be secured from the individual copyright owners to reproduce any copyrighted materials contained within this report.

Suggested citation:

Balser, A.W., and Wylie, B.K., 2010, Multitemporal L- and C-band synthetic aperture radar to highlight differences in water status among boreal forest and wetland systems in the Yukon Flats, interior Alaska: U.S. Geological Survey Open-File Report 2010-1027, 18 p., 2 app. 


\section{Contents}

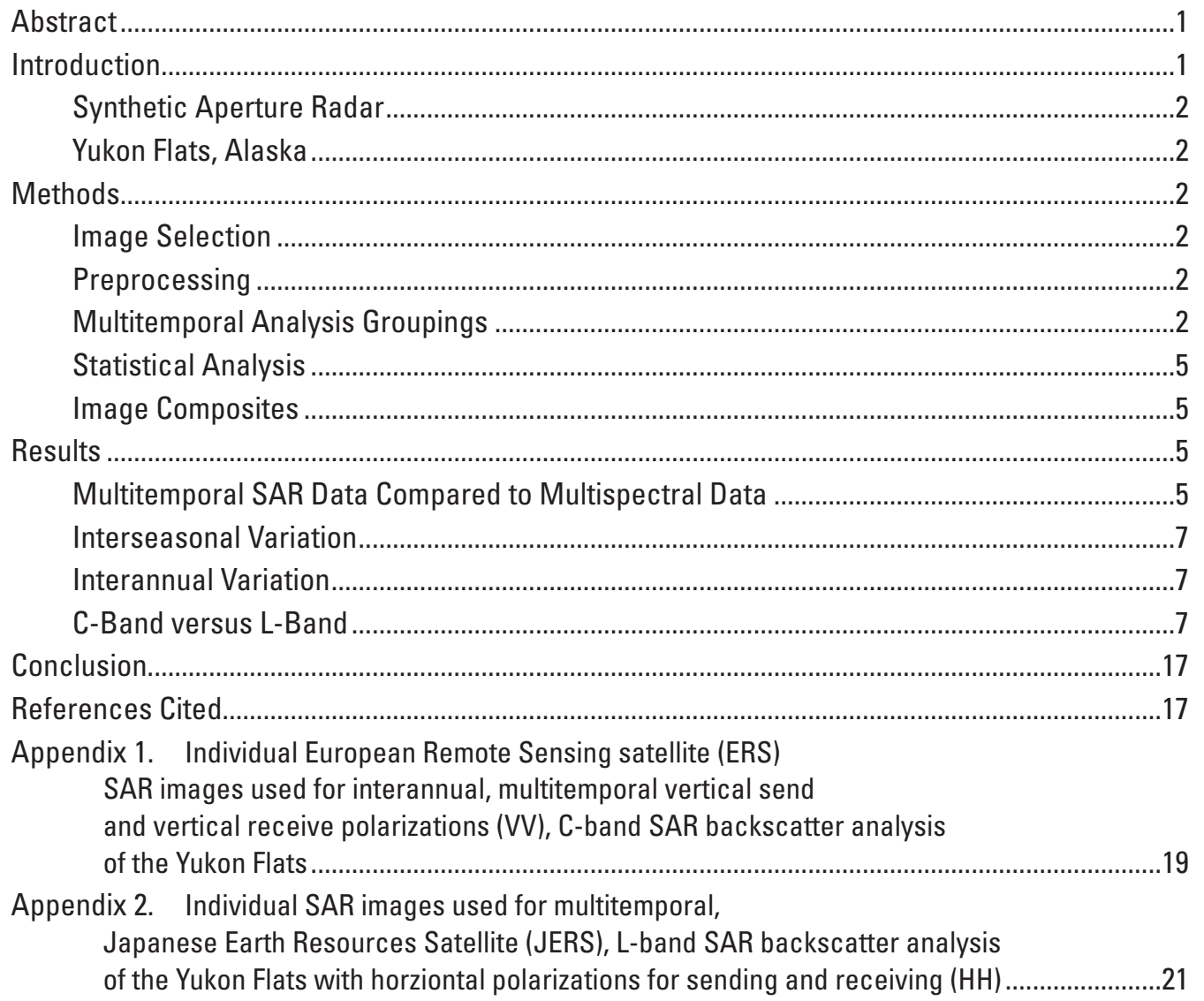

\section{Figures}

1. The Yukon River Basin and the Yukon Flats study area in Alaska.............................................

2. The Lower Mouth Birch Creek focus area within the Yukon Flats study area in Alaska

3. Derivative Thermal, Normalized Difference Vegetation Index, Normalized Difference Moisture Index color composite from 2007 Landsat Enhanced Thematic Mapper Plus data .........................................6

4. Color-Infrared composite of Landsat Enhanced Thematic Mapper

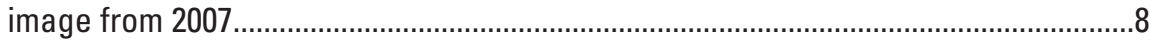

5. European Remote Sensing satellite (ERS) multitemporal classification.................................

6. 2007 European Remote Sensing satellite (ERS) false-color composite of May (blue), July (green), and September (red) seasonal imagery........................10

7. Japanese Earth Resources Satellite (JERS) multitemporal classification .............................11

8. European Remote Sensing satellite (ERS) classifications from 1993 (A) and 1997 (B) ..........12

9. European Remote Sensing satellite (ERS-1) false-color composite from 1993 .....................14

10. European Remote Sensing satellite (ERS-2) false-color composite from 2007 ..............................15

11. Interannual false-color composite C-band backscatter in July ..................................................16 


\section{Tables}

1. Multitemporal SAR analysis groupings

2. Hectares of each landscape type by year using

European Remote Sensing satellite (ERS) data

\section{Conversion Factors}

Inch/Pound to SI

\begin{tabular}{|c|c|c|}
\hline Multiply & By & To obtain \\
\hline \multicolumn{3}{|c|}{ Area } \\
\hline acre & 4,047 & square meter $\left(\mathrm{m}^{2}\right)$ \\
\hline acre & 0.4047 & hectare (ha) \\
\hline acre & 0.4047 & square hectometer $\left(\mathrm{hm}^{2}\right)$ \\
\hline acre & 0.004047 & square kilometer $\left(\mathrm{km}^{2}\right)$ \\
\hline
\end{tabular}

Temperature in degrees Celsius $\left({ }^{\circ} \mathrm{C}\right)$ may be converted to degrees Fahrenheit $\left({ }^{\circ} \mathrm{F}\right)$ as follows:

${ }^{\circ} \mathrm{F}=\left(1.8 \mathrm{x}^{\circ} \mathrm{C}\right)+32$ 


\title{
Multitemporal L- and C-Band Synthetic Aperture Radar To Highlight Differences in Water Status Among Boreal Forest and Wetland Systems in the Yukon Flats, Interior Alaska
}

\author{
By Andrew W. Balser ${ }^{1}$ and Bruce K. Wylie ${ }^{2}$
}

\begin{abstract}
Tracking landscape-scale water status in high-latitude boreal systems is indispensible to understanding the fate of stored and sequestered carbon in a climate change scenario. Spaceborne synthetic aperture radar (SAR) imagery provides critical information for water and moisture status in Alaskan boreal environments at the landscape scale. When combined with results from optical sensor analyses, a complementary picture of vegetation, biomass, and water status emerges. Whereas L-band SAR showed better inherent capacity to map water status, C-band had much more temporal coverage in this study. Analysis through the use of L- and C-band SARs combined with Landsat Enhanced Thematic Mapper Plus $(\mathrm{ETM}+)$ enables landscape stratification by vegetation and by seasonal and interannual hydrology. Resultant classifications are highly relevant to biogeochemistry at the landscape scale. These results enhance our understanding of ecosystem processes relevant to carbon balance and may be scaled up to inform regional carbon flux estimates and better parameterize general circulation models (GCMs).
\end{abstract}

\section{Introduction}

Carbon balance at high latitudes is heavily influenced by changes in water status and temperature from local to regional scales. The circumarctic boreal zone makes up only 15 percent of earth's land surface while storing over 30 percent of earth's terrestrial carbon (Chapin and others, 2000). Temperature and water status are primary biogeochemical drivers that determine carbon fate in these systems (Camill and others, 2001; Jorgenson and others, 2007; Wickland

\footnotetext{
${ }^{1}$ University of Alaska Fairbanks, Institute of Arctic Biology, Fairbanks, AK 99775.

${ }^{2}$ U.S. Geological Survey, Earth Resources Observation and Science Center, Sioux Falls, SD 57198.
}

and Neff, 2008). Between 1954 and 2003, annual average temperatures in the Arctic rose about $1{ }^{\circ} \mathrm{C}$, and average winter temperatures increased $2-4^{\circ} \mathrm{C}$ (ACIA, 2004). Results from general circulation models (GCMs) indicate that average annual temperatures in the Arctic may rise a further $3-5^{\circ} \mathrm{C}$ and winter temperatures may increase by $4-7^{\circ} \mathrm{C}$ (IPCC, 2007). Changes to hydrologic patterns are very poorly documented, yet are of equal importance to carbon net ecosystem exchange (NEE) estimates (Hinzman and others, 2005). Recent studies indicate that changes to water status may alter a site from carbon sink to source and vice versa in boreal ecosystems (Schuur and others, 2007). Better quantification of landscape hydrologic patterns in boreal regions will expand our processbased understanding of boreal ecosystems, illustrate their role and importance in regional to circumarctic biogeochemical cycling, and improve scaling of terrestrial carbon pool estimates to better parameterize GCMs.

Spatial characterization of water status and hydrologic patterns in boreal forests and wetlands has been extremely elusive because those are largely subsurface phenomena. Even hydric and flooded soils are difficult to identify synoptically when obscured by emergent or inundated vegetation. Optical sensors operating in visible to infrared wavelengths are fully capable of mapping open water and have some success in detecting moisture by using the normalized difference moisture index (NDMI), or by using temperature (Wilson and Sader, 2002; Lillesand and others, 2008). These wavelengths are rarely long enough to penetrate through a vegetated canopy (Ulaby, 1982), leaving much of the soil moisture story untold. A major additional limitation is weather condition. Cloud cover, haze, and smoke from wildfires obscure the landscape for optical sensors. Typical repeat cycles are roughly 14 days, so there are only a few opportunities to collect data during the snow-free growing season in subarctic settings. It is often challenging to acquire a single, quality optical image for a boreal landscape during a given year, and the prospect of intraseasonal data to capture hydrologic variability within the growing season is very remote. 


\section{Synthetic Aperture Radar}

Satellite-based synthetic aperture radar (SAR) imagery provides multitemporal information for water and moisture status in Alaskan boreal landscapes. Satellite-based radar platforms (European Remote Sensing satellite [ERS-1, ERS-2], Japanese Earth Resources Satellite [JERS], and RADARSAT-1) all operate in the microwave portion of the electromagnetic spectrum to which clouds, haze, and airborne particulates are entirely transparent (Ulaby, 1982). Typical repeat cycles for SAR platforms are similar to optical sensors of comparable spatial resolution, but the certitude of data acquisition regardless of cloud cover makes intraseasonal and interannual landscape analysis possible (Duguay, 1999).

Microwave energy is highly sensitive to water in a liquid state because the dielectric constant of liquid watereither alone or incorporated into soil matter and plant tissues - comprises a highly reflective property to propagated microwave energy (Ulaby and others, 1996). Soil moisture as a direct measurement is substantially confounded in SAR analysis by vegetative cover. It is the essential interactions of soil moisture, plant tissue water status, and the quantity and nature of plant biomass that drive backscatter response (French and others, 1996; Ulaby and others, 1996).

Multitemporal SAR analysis has been shown to accurately classify general land cover by the combination of vegetation and water status dynamics (Balser, 1996).

In contrast, Landsat Thematic Mapper (TM), Enhanced Thematic Mapper (ETM), and ETM+ data are a proven standard for surface vegetation mapping at the landscape scale (Lillesand and others, 2008). Landsat's multispectral data offer the analytical capability to discriminate among an extremely broad variety of materials and compounds on a land surface. Classification algorithms make statistical use of this spatially explicit, multivariate data to group the landscape into distinct land cover classes. The algorithms may range from the very simple to the very complex, but the underlying capability rests in rich quantities of relevant multivariate data for a specific moment or snapshot in time.

Multitemporal SAR data are complementary to multispectral optical data because both rely on rich multivariate information of distinctly different types to drive analytical results. Landscape characteristics that show change in SAR seasonal and interannual observations allow classification on the basis of temporal patterns, whereas Landsat data record plant tissue and substrate differences among multiple spectra.

\section{Yukon Flats, Alaska}

The Yukon Flats comprise 9 million acres of boreal forest, wetland, and aquatic habitats within the Yukon Flats National Wildlife Refuge (U.S. Fish and Wildlife Service) (fig. 1). Minimal topographic relief throughout the region (fig. 2) results in complex hydrologic patterns, substrates, and vegetation distributions. These cold, wet lowlands in the Discontinuous Permafrost Zone are estimated to have between 75 and 90 percent permafrost extent (Jorgenson and others, 2008). The Yukon Flats are typical of a large part of the boreal zone in North America that stretches from Alaska through northwestern to eastern Canada. As a region, it is biogeochemically representative of a large percentage of total terrestrial habitat in Alaska and Canada.

Soils, permafrost distribution, and hydrologic patterns are poorly catalogued at the landscape scale, yet local site variability in NEE of carbon is expected to be heavily affected by these unseen influences (Turetsky and others, 2007). For these reasons, the Yukon Flats are of great interest for biogeochemical work aided by improved mapping of hydrologic patterns.

\section{Methods}

\section{Image Selection}

Archives at the Alaska Satellite Facility (ASF) were searched for all ERS C-band and JERS L-band SAR imagery which (1) completely covered the Lower Mouth Birch Creek focus area (fig. 2), (2) were acquired between May 1 and October 15 (for ERS only), and (3) spanned all years from 1991 (launch of ERS-1) to 2007 (ERS-2 continuing operations). RADASAT-1 data were also queried, but the number of snow-free images available (and not recorded in ScanSAR mode) were relatively few. For this reason, ERS data were selected for C-band analysis.

A total of 43 ERS C-band images spanning May 12, 1993, to September 18, 2007, met all criteria and were delivered by ASF (app. 1). Fourteen suitable JERS L-band images were available (app. 2).

\section{Preprocessing}

Preprocessing included (1) georectification, (2) filterbased speckle suppression, and (3) a final first order (Affine) geolocational adjustment. Each image was preprocessed by using ASF MapReady 2.1, with geocoding and terrain correction based on the USGS National Elevation Dataset (NED). All images were filtered for speckle effects by using ERDAS Imagine 9.0 with a $3 \times 3$ kernel Lee-Sigma filter with 0.2 coefficient of variation. Final X-Y shift adjustments were performed with the ERDAS geometric correction tool and a first order polynomial.

\section{Multitemporal Analysis Groupings}

The rich archive of ERS data enabled several types of multitemporal analysis. First, ERS data were grouped by year 


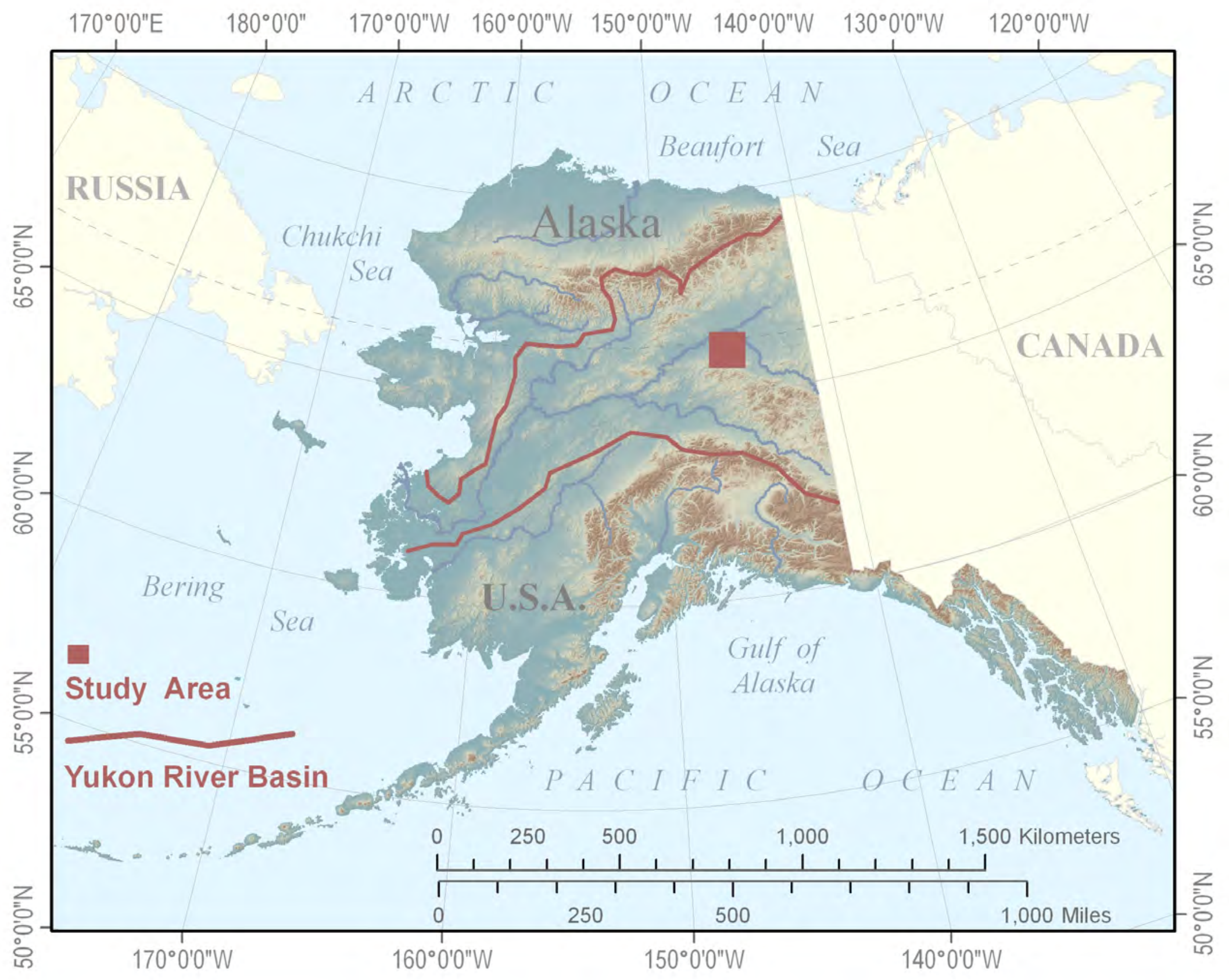

Figure 1. The Yukon River Basin and the Yukon Flats study area in Alaska. 


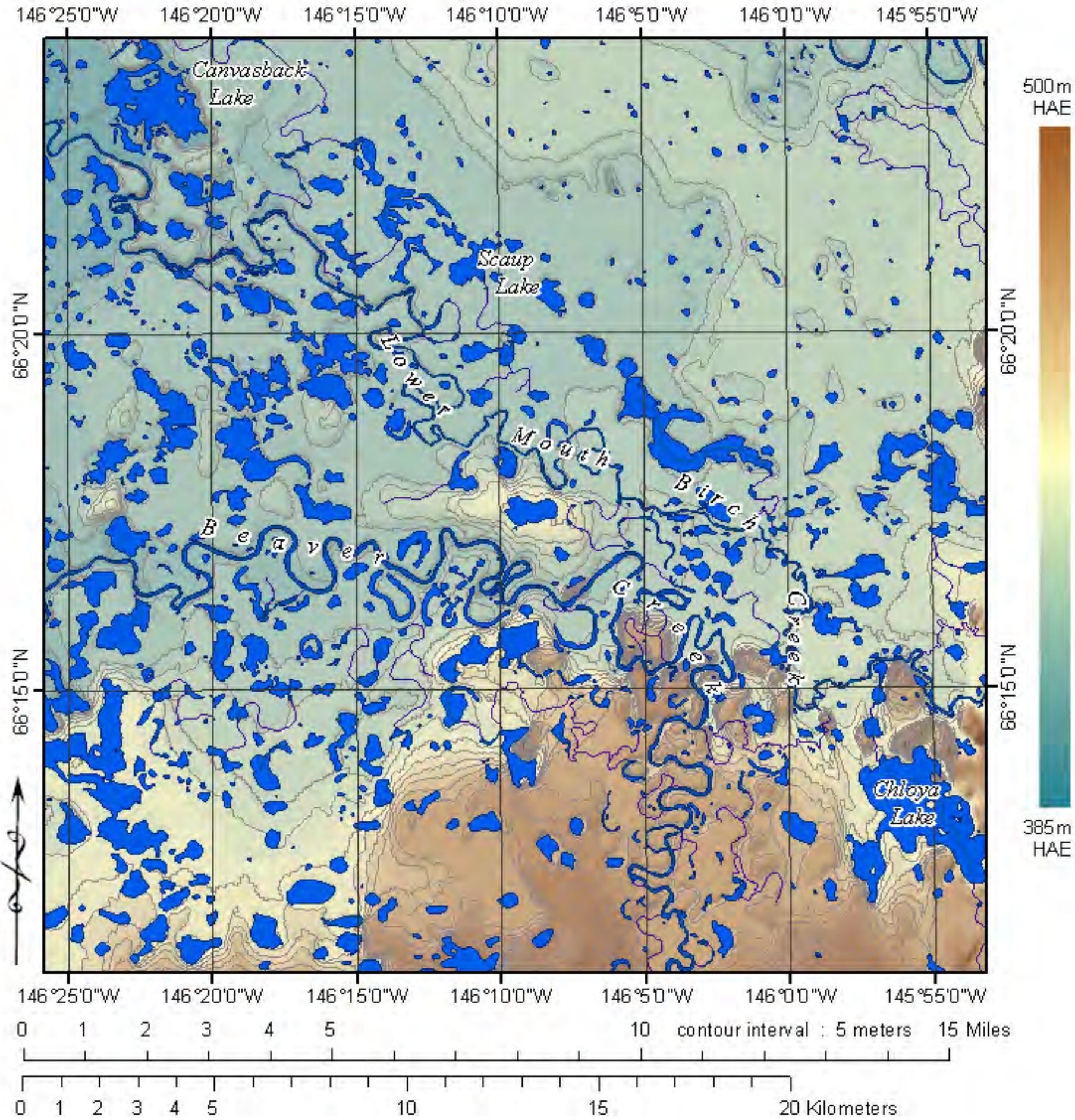

Figure 2. The Lower Mouth Birch Creek focus area within the Yukon Flats study area in Alaska. Note that the entire span of elevation is only $115 \mathrm{~m}$ over an area of more than $45 \mathrm{~km}$. 
for the following years of data within this study: 1993, 1997, 1998, 1999, 2004, 2005, 2006, and 2007. Next, data were grouped by seasonal phenology: May, June, July, August, and September/October. Finally, all ERS data were combined as a single group.

JERS data were limited to 14 images spread from 1993 to 1998 . For this reason, L-band data had one single grouping of all images.

\section{Statistical Analysis}

This study is focused on determining what types of information are contained within multitemporal SAR data for boreal landscapes. Beyond the presumption that results would strongly reflect landscape biomass and hydrologic conditions, no predetermined classes were defined, and the only specific class to be expected was that of completely unvegetated open water.

IsoData clustering (Lillesand and others, 2008) was chosen as the most statistically robust and proven method for teasing apart landscape dynamics with multitemporal SAR data. Clustering algorithms were run in ERDAS Imagine 9.0 by using 15 classes with a maximum 10 iterations and convergence of 0.95 . The clustering routine was run on each analysis grouping (table 1). Results were interpreted against several sources of reference imagery including (1) Alaska High Altitude Aerial Photography Program (AHAP) photos (1980s), (2) Google Earth-supplied QuickBird imagery, (3) Landsat TM, ETM, and ETM+ imagery from several years (1999, 2000, 2007), and (4) the Landsat derivative composite of thermal, NDVI, and NDMI products calculated from 2007 Landsat ETM+ imagery (fig. 3).

Table 1. Multitemporal SAR analysis groupings.

\begin{tabular}{lllc}
\hline \multicolumn{1}{c}{ Year } & Band & Sensor & $\begin{array}{c}\text { Number of } \\
\text { image scenes }\end{array}$ \\
\hline 1993 & C & ERS-1 & 5 \\
1997 & C & ERS-2 & 5 \\
1998 & C & ERS-2 & 7 \\
1999 & C & ERS-2 & 5 \\
2004 & C & ERS-2 & 5 \\
2005 & C & ERS-2 & 3 \\
2006 & C & ERS-2 & 4 \\
2007 & C & ERS-2 & 5 \\
$1993-2007$ & C & ERS-2 & 39 \\
$1993-1998$ & L & JERS & 14 \\
\hline
\end{tabular}

\section{Image Composites}

Red, green, and blue false color composites were produced from ERS and JERS SAR analysis groupings. Composite images combinations included (1) interseasonal composites within years and (2) interannual composites of specific phenologic periods. These were analyzed for differences in interannual landscape patterns and for differences in spatial patterns within defined phenologic periods.

\section{Results}

Interannual variability in hydrologic pattern is notable and complex (table 2). The number of hectares of each super class (Constant Inundation, Shrub/Forb/Herb Dominated, and Forest/Tall Shrub Dominated) fluctuates to vaguely suggest relatively "wet" or "dry" years at the regional scale. The more accurate interpretation, however, is far more spatially and temporally complex.

Different components of the landscape are hydrologically impacted by different events at different scales and during different seasons. For example, a graminoiddominated wetland which is hydrologically tied to a nearby creek or river will have a buffered response to changes in local rainfall through the season. A similar wetland which is segregated from adjacent hydrology by permafrost will be recharged exclusively through local precipitation as rainfall and spring snowmelt. Other areas may be hybrids, with variable response times to hydrologic events based on combinations of soil, permafrost, and vegetative interactions. Results are more meaningful in the context of their spatial context.

\section{Multitemporal SAR Data Compared to Multispectral Data}

The capacity of SAR to map variations that may be missed by optical sensors is most apparent in small ponds and wetlands. Note the difference between these features in Landsat (they appear either purely terrestrial or purely aquatic) (figs. 3, 4) compared with multitemporal SAR classifications and composite images (figs. 5, 6, 7, 8). While Landsat clearly shows differences in vegetation type that SAR cannot easily detect, SAR can distinguish intermittent wetlands from lakes and ponds, and from terrestrial habitat. This information suggests a very different interpretation of the landscape and its biogeochemical processes. 


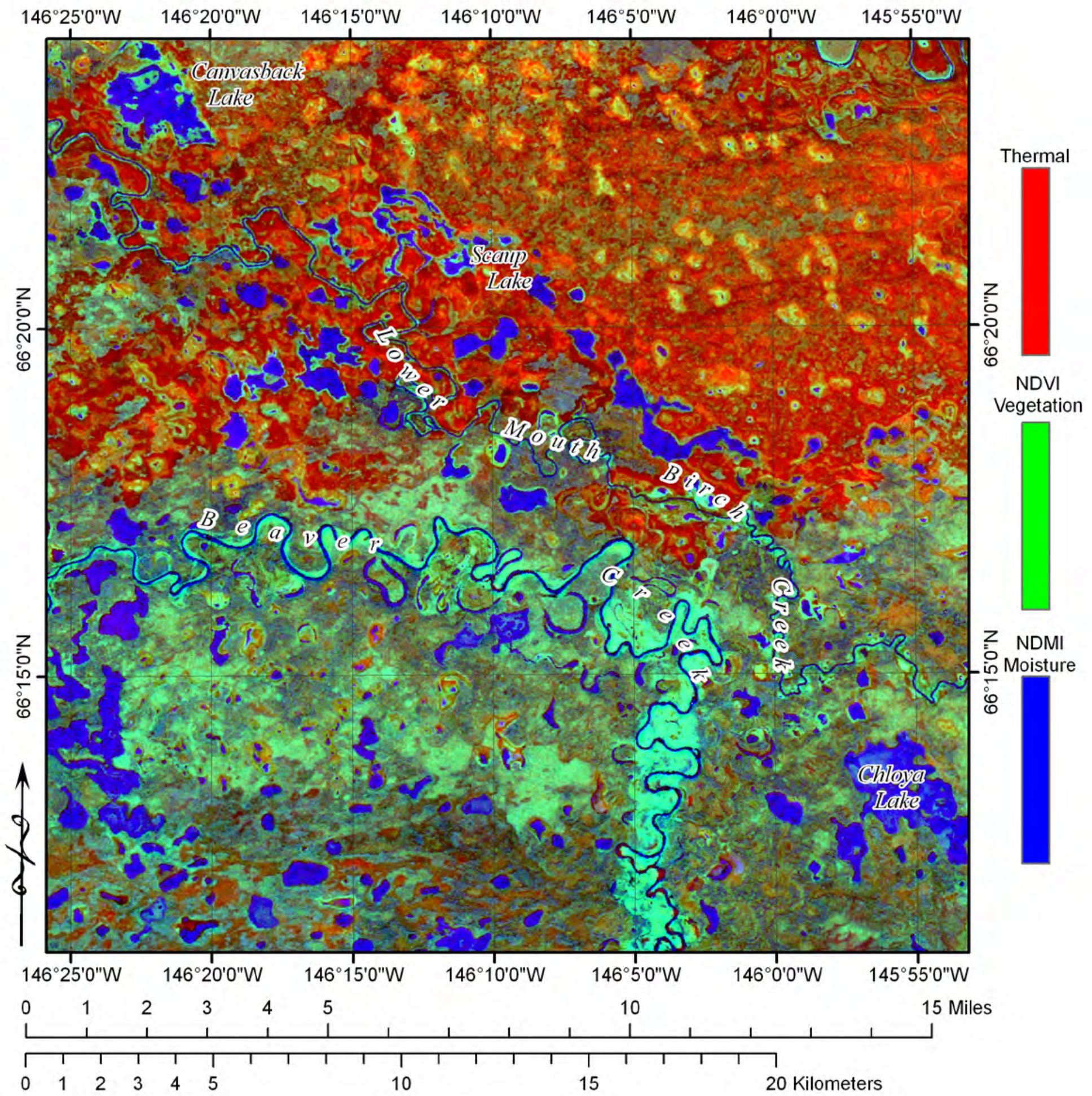

Figure 3. Derivative Thermal, Normalized Difference Vegetation Index, Normalized Difference Moisture Index color composite from 2007 Landsat Enhanced Thematic Mapper Plus data. Note extensive burn (2004) as red terrain. 
Table 2. Hectares of each landscape type by year using European Remote Sensing satellite (ERS) data.

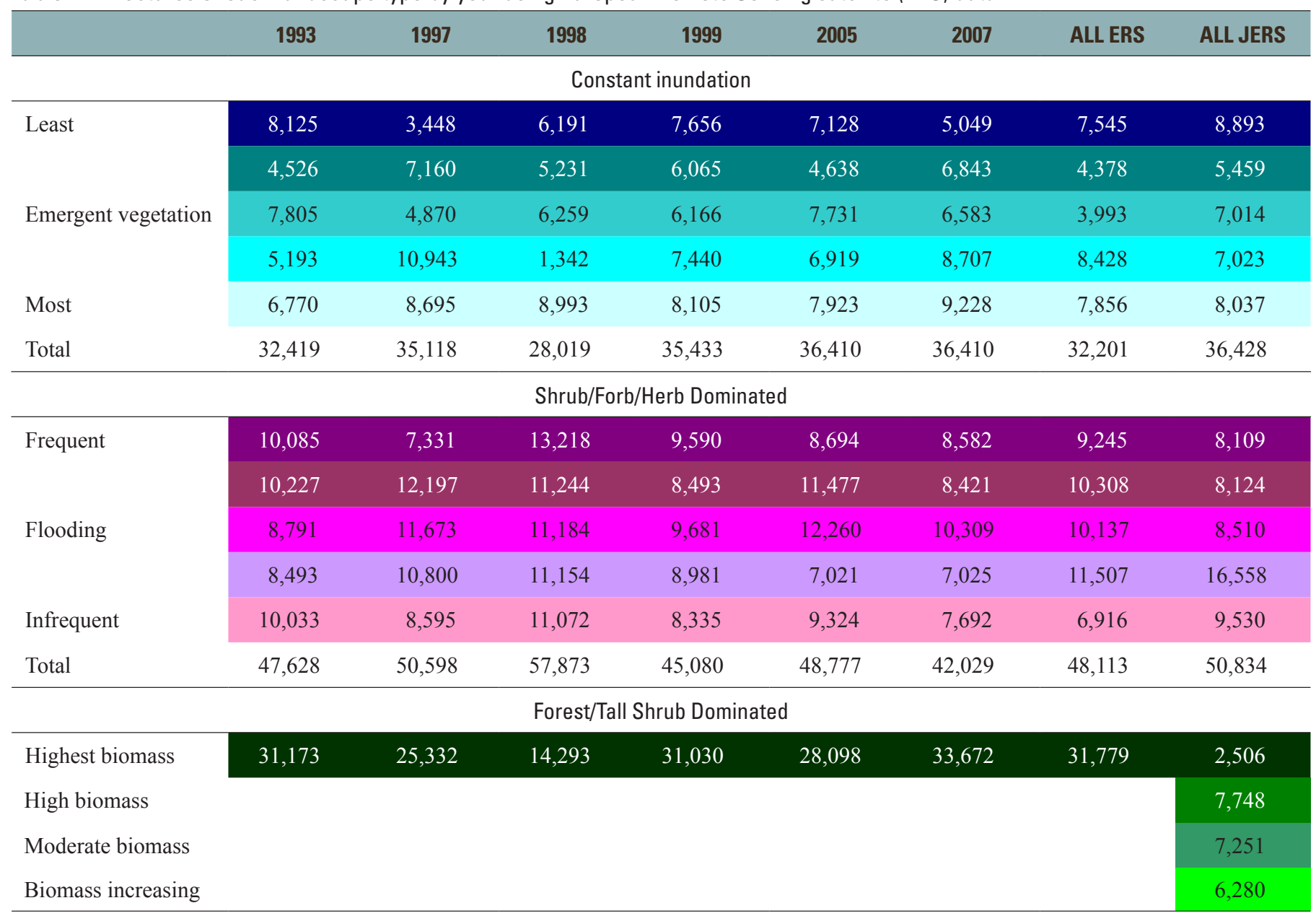

\section{Interseasonal Variation}

Both typical and anomalous seasonal patterns may be detected with multitemporal SAR. In figures 9 and 10, a small area (bright yellow) in the east-central portion of the map retains the same interseasonal characteristics even after heavy modification by wildfire. The high backscatter in July and September for both years indicates a site that begins the season wet but dries quickly and tends to remain that way with the possible exception of short-lived recharge events.

Conversely, figure 11 shows seasonal anomalies. In the northern part of the map, the yellow anomaly has a known cause: landscape disturbance by wildfire which has changed the landscape structure and possibly its capacity to retain soil and plant tissue water during the summer. To the south, many small lakes and ponds had very high backscatter along their margins in 1993. A likely interpretation is that 1993 was a wetter year, and pond levels rose to inundate more vegetation around their margins, causing increased double-bounce scattering and higher backscatter returns.

\section{Interannual Variation}

According to table 2, 1993 and 1997 were very different in terms of flood frequency and proportion of inundated vegetation. The coarse interpretation is that 1993 was relatively wetter, and 1997 was relatively drier. The classification results bear this out but add descriptive detail with spatially explicit differences (fig. 8). Most lakes and ponds appear to have had more emergent biomass (and corresponding lower water levels) in 1997. Intermittently flooded shrublands also appear to have received less frequent recharge in 1997.

\section{C-Band versus L-Band}

L-band (JERS) data are more conducive for mapping and analyzing landscapes with higher biomass than are C-band (ERS) data. Both bands appear capable of mapping the same types of landscape phenomena (hydrologic pattern coupled with vegetative cover), but L-band seems to enable analysis of 


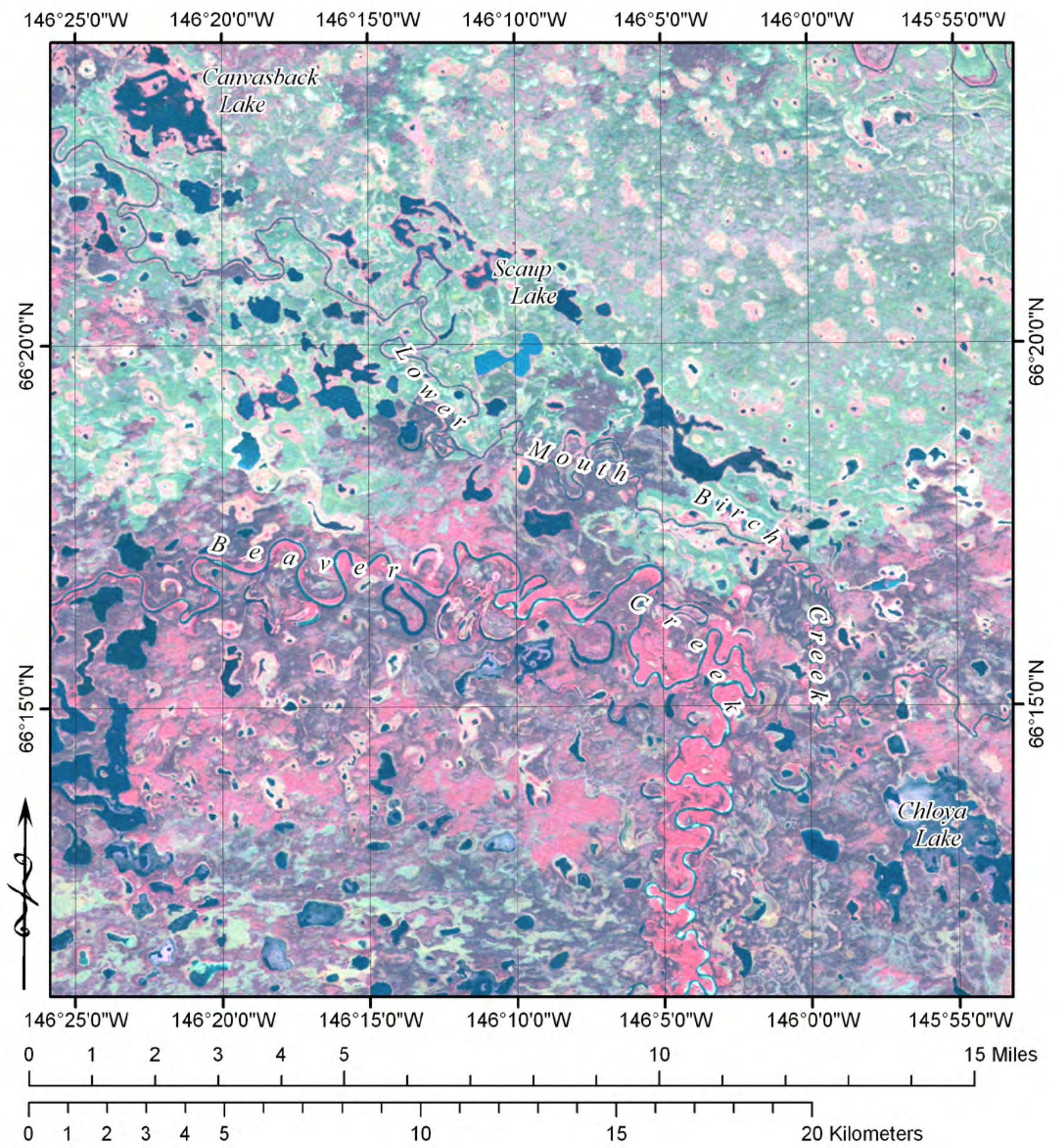

Figure 4. Color-Infrared composite of Landsat Enhanced Thematic Mapper image from 2007. Note extensive burn (2004) as green terrain. 


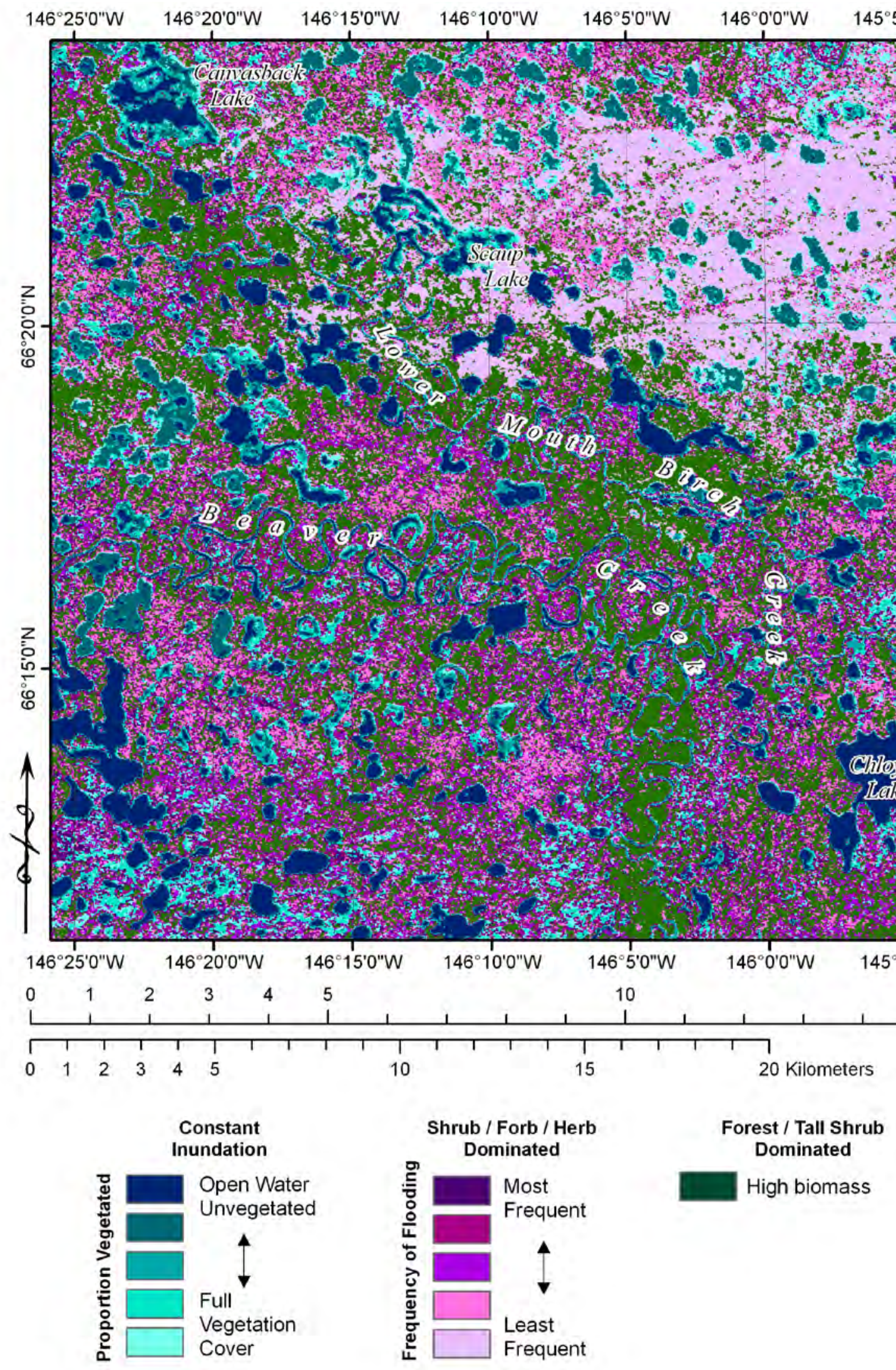

Figure 5. European Remote Sensing satellite (ERS) multitemporal classification. Note the detection of emergent vegetation and lakes with variable water levels compared with Landsat (figs. 3, 4). 


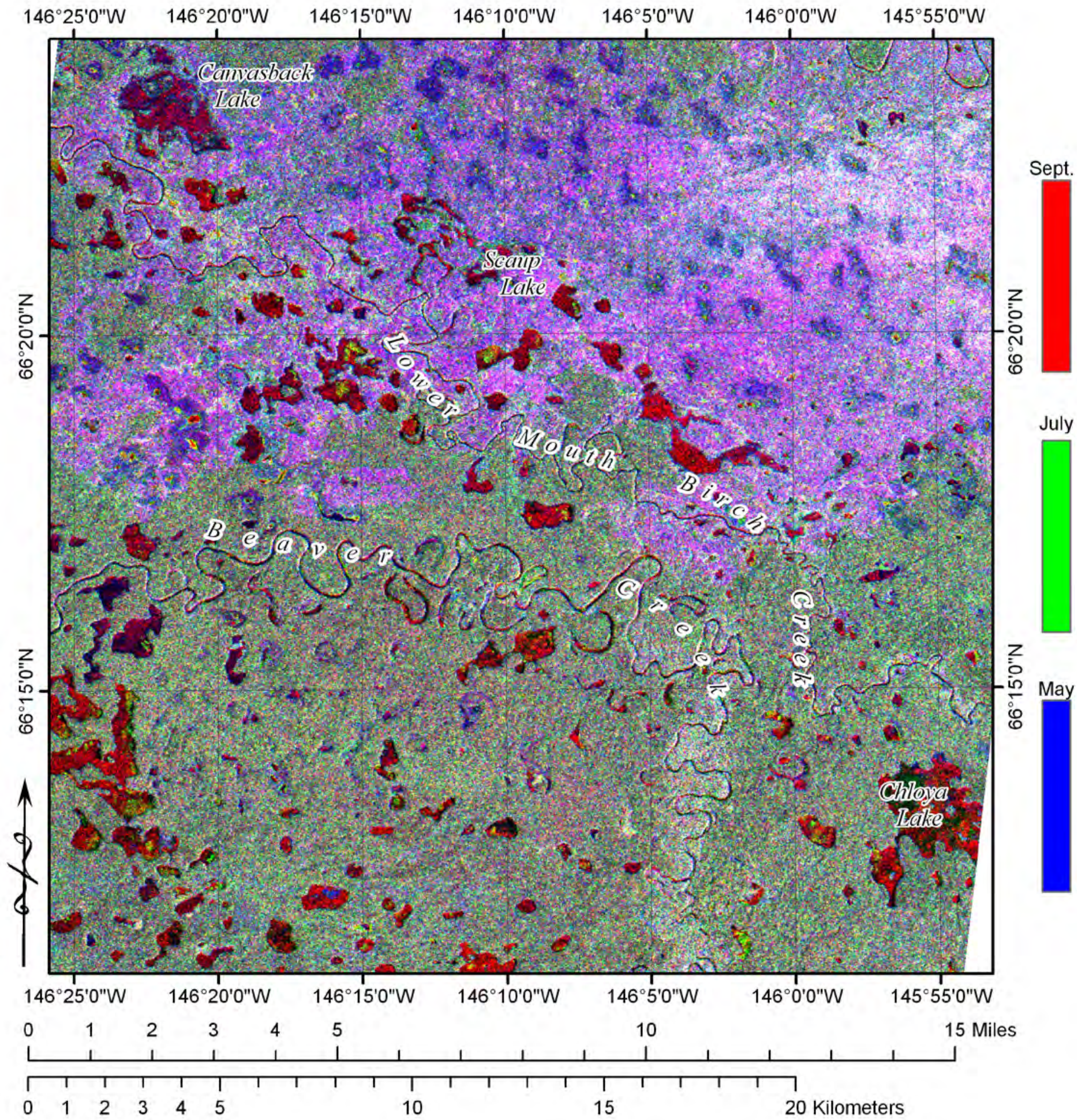

Figure 6. 2007 European Remote Sensing satellite (ERS) false-color composite of May (blue), July (green), and September (red) seasonal imagery. Note conspicuous change in water level (red) in September. 


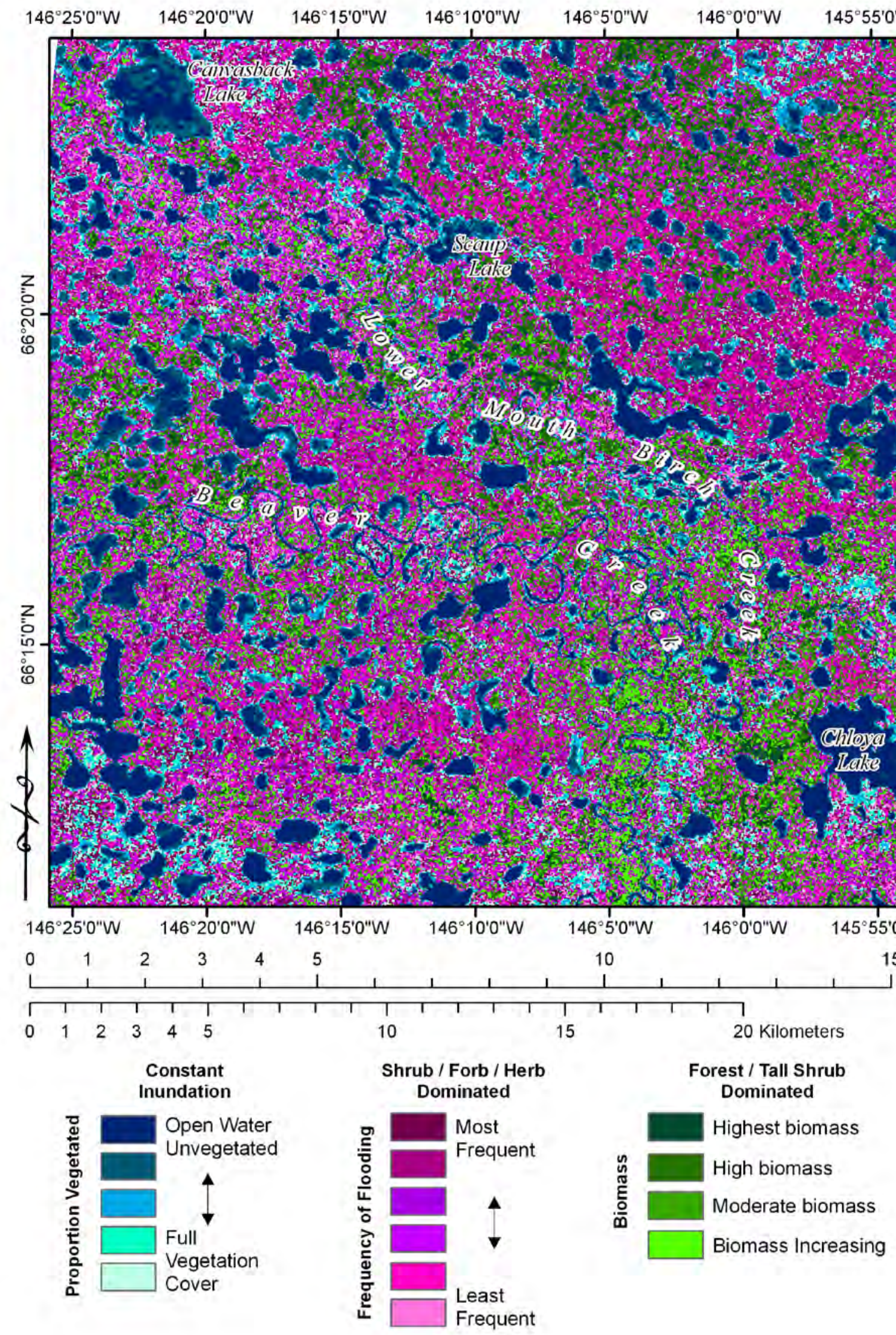

Figure 7. Japanese Earth Resources Satellite (JERS) multitemporal classification. Note the improved capacity to map higher biomass landscapes over C-band data (fig. 5). Also note greater variability in inundated landscapes over Landsat (figs. 3, 4). 
$\boldsymbol{A}$
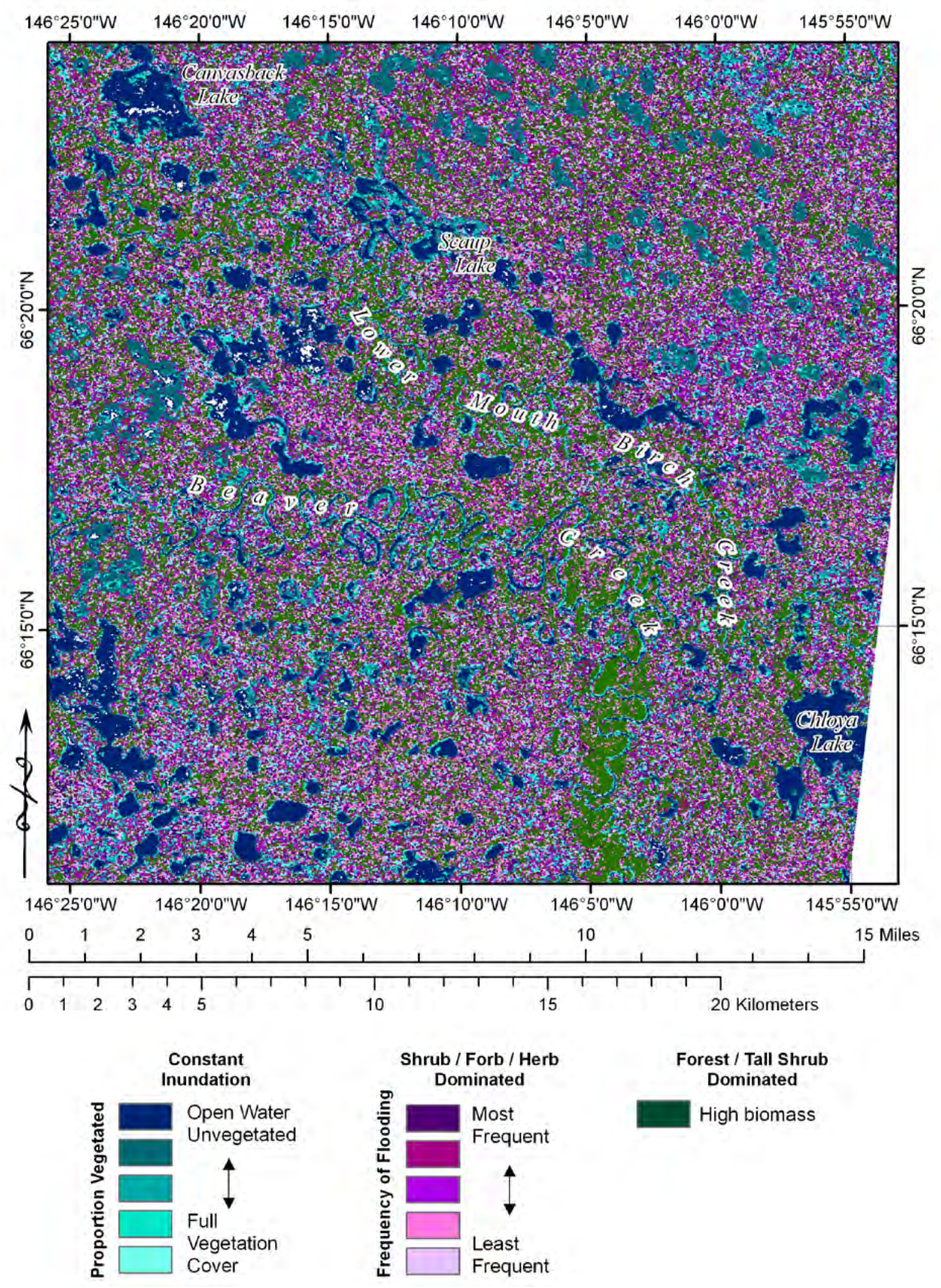

High biomass

Figure 8. European Remote Sensing satellite (ERS) classifications from $1993(A)$ and $1997(B)$. Table 2 shows them to be very different years in terms of proportional representation of mapped classes. 1997 was a much drier year overall, and ponds and wetlands along the Lower Mouth Birch Creek drainage valley appear driest within this map frame. Conditions in the northeast corner of the 1997 classification exceeded the high biomass threshold in the intervening years, and the northeast corner is therefore not considered in this comparison. 


\section{B}

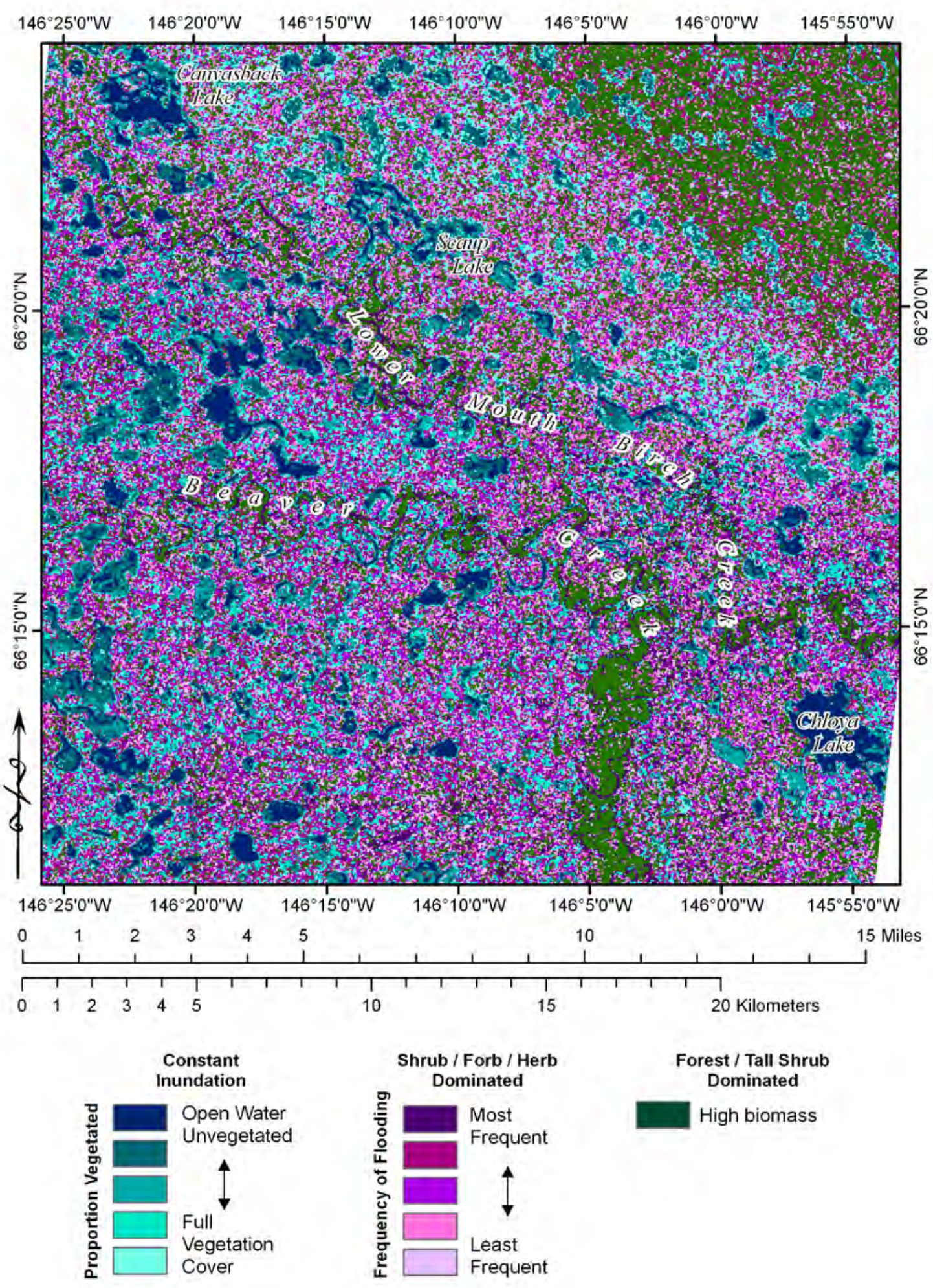




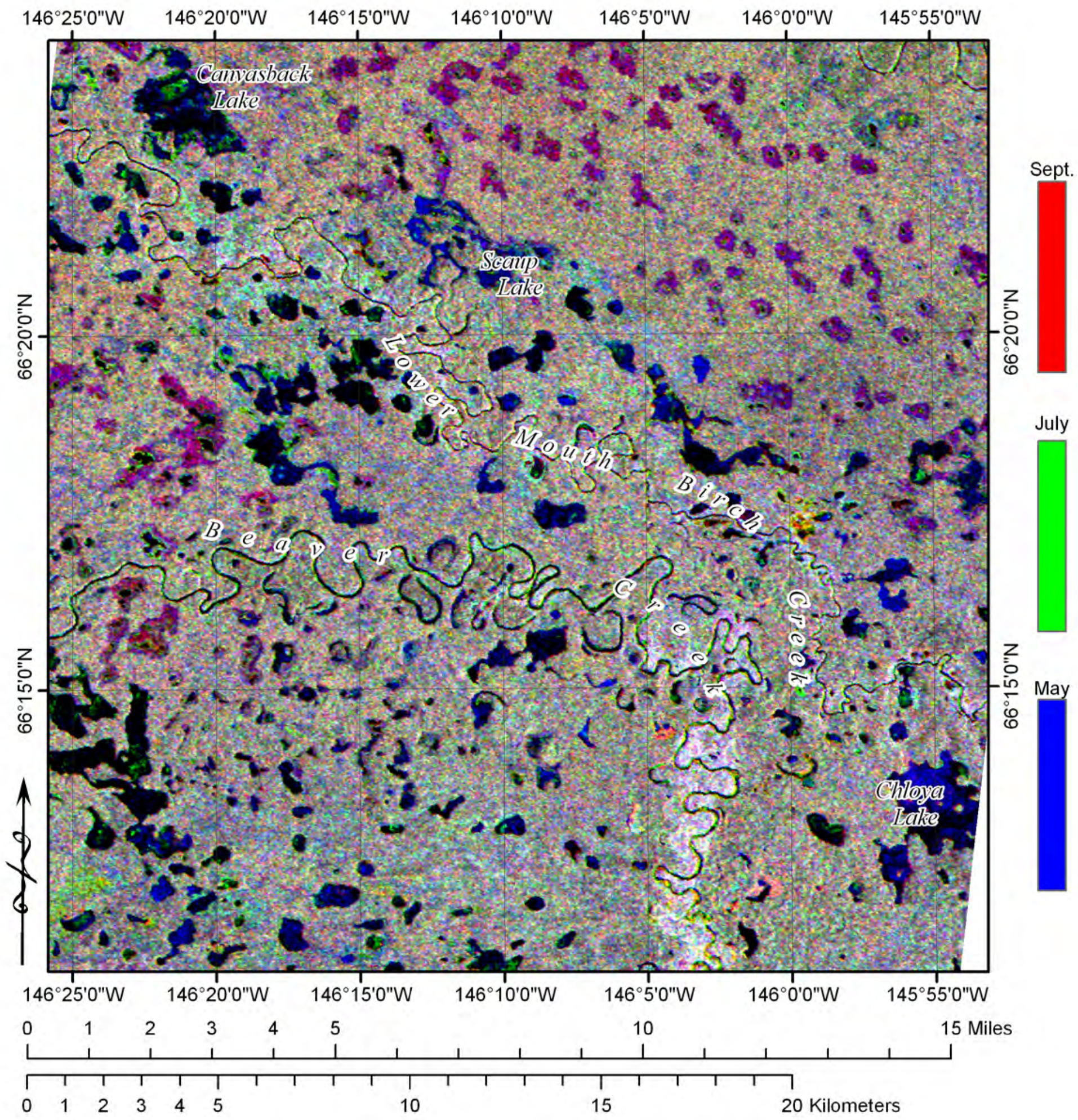

Figure 9. European Remote Sensing satellite (ERS-1) false-color composite from 1993. Note the differing hydrologic phenology between these dates (north-central, south-central, and western portions of imagery). 


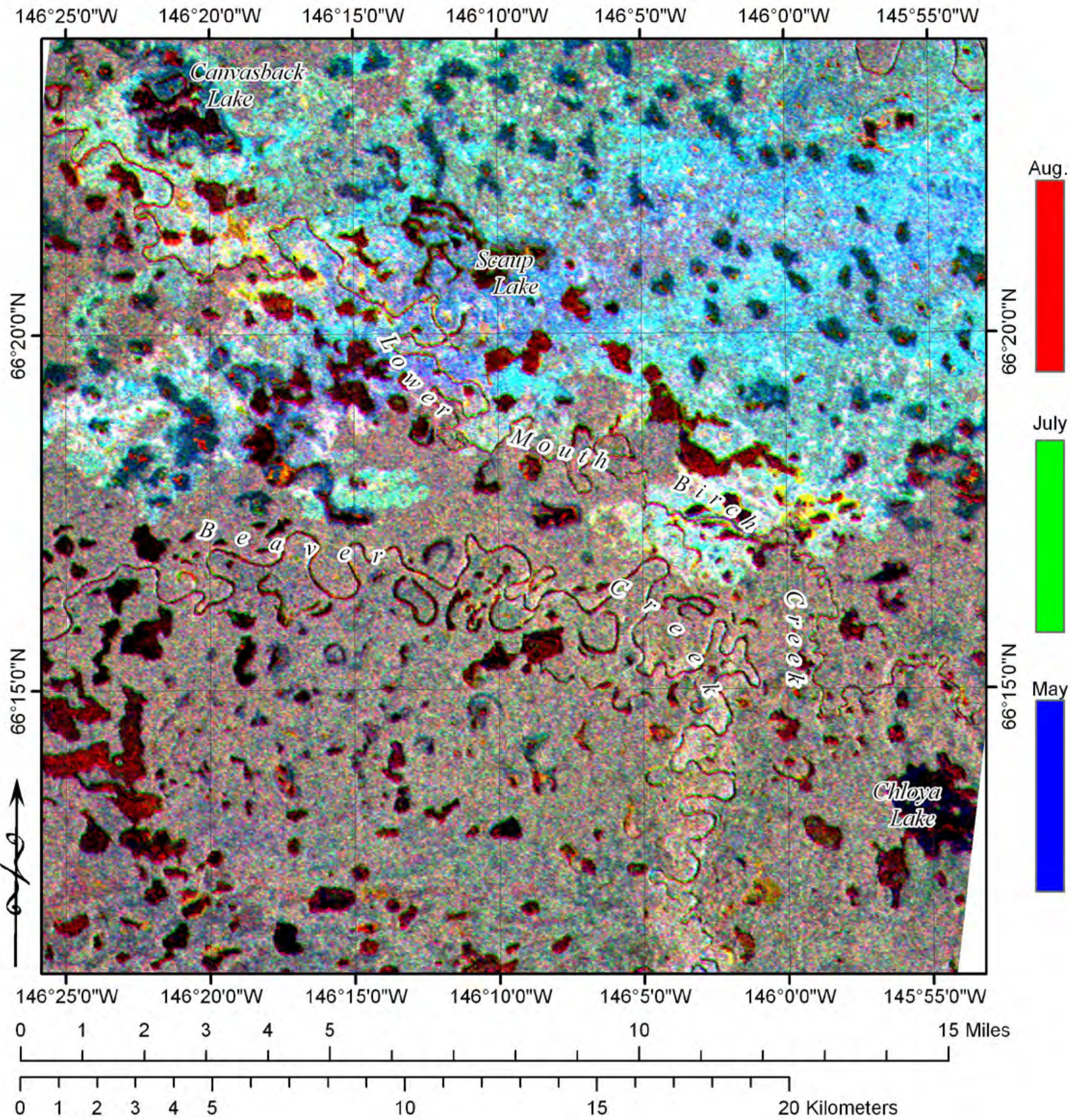

Figure 10. European Remote Sensing satellite (ERS-2) false-color composite from 2007. Effects of the 2004 fire are obvious (blue), but some preexisting effects stand out very strongly. Note the bright yellow area in the east-central part, which tends to dry out early and remain that way according to the bright yellow signature. 


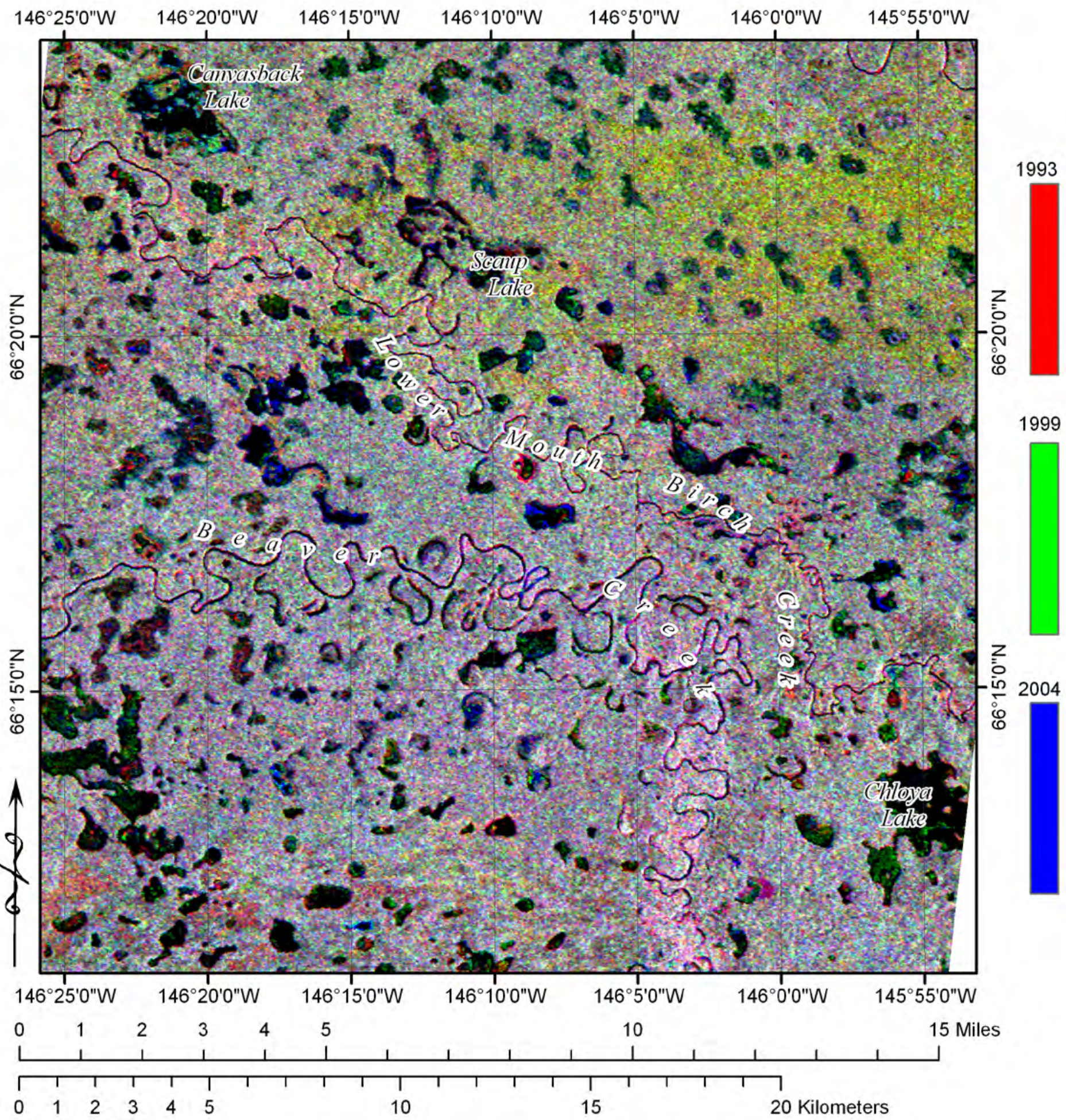

Figure 11. Interannual false-color composite C-band backscatter in July. Anomalous local conditions stand out in bright red on a number of small lakes. 
a higher percentage of the landscape without having to assign a single, catchall class of high biomass where sensitivity of the sensors diminishes.

\section{Conclusion}

Multitemporal SAR analysis has clear capabilities to enhance landscape mapping and monitoring in the Yukon River Basin. Biogeochemically critical patterns of wetting and drying are detectable to a much higher degree than with traditional optical sensor data.

Although L-band is typically considered preferable to C-band for this application because of its capacity to analyze a broader range of landscapes based on biomass, there were not enough data available in the archive to conduct a credible interannual analysis. JERS data then may enhance analyses using C-band data and may also be of great value for decadal, time-step, mapping efforts. C-band data, which are routinely available interseasonally for each year since 1993, offer the best alternative for comparing specific years and specific seasons within and among years for areas of low to moderate (shrub-dominated) landscapes.

Whereas results of SAR analysis may reasonably be interpreted by using multiple ancillary data (such as airphotos or optical satellite data), additional information from field studies will be necessary to further confirm these findings and to add detail to the classification and band-composite analysis results to date. Field excursions in 2009 are expected to yield information essential to the further interpretation of these results.

\section{References Cited}

ACIA (Arctic Climate Impact Assessment), 2004, Impacts of a warming Arctic - Arctic Climate Impact Assessment: Cambridge University Press.

ACIA, 2004, Impacts of a warming Arctic - Arctic Climate Impact Assessment: Cambridge University Press.

Balser, A.W., 1996, Combining Landsat TM and multi-temporal ERS-1 imagery to improve classification accuracy and detail in the Tanana Flats Wetlands Complex, Interior Alaska: Fairbanks, M.S. thesis, University of Alaska, Fairbanks.

Camill, P., Lynch, J.A., Clark, J.S., Adams, J.B., and Jordan, B., 2001, Changes in biomass, aboveground net primary production, and peat accumulation following permafrost thaw in the boreal peatlands of Manitoba, Canada: Ecosystems, v. 4, p. 461-478.
Chapin, S.F., McGuire, D.A., Randerson, J., Pielke, R., Baldocchi, D., Hobbie, E.S., Roulet, N., Eugster, N., Kasischke, E., Rastetter, B.E., Zimov, A.S., and Running, W.S., 2000, Arctic and boreal ecosystems of western North America as components of the climate system: Global Change Biology, v. 6, p. 211-223.

Duguay, C.R., Rouse, W.R., Lafleur, P.M., Boudreau, L.D., Crevier, Y., and Pultz, T.J., 1999, Analysis of multi-temporal ERS-1 SAR data of subarctic tundra and forest in the northern Hudson Bay Lowland and implications for climate studies: Canadian Journal of Remote Sensing, v. 25, p. 21-33.

French, N.H.F., Kasischke, E.S., Bourgeau-Chavez, L.L., and Harrell, P.A., 1996, Sensitivity of ERS-1 SAR to variations in soil water in fire-disturbed boreal forest ecosystems: International Journal of Remote Sensing, v. 17, p. 3037 3053 .

Hinzman, L., Bettez, N., Bolton, W., Chapin, F., Dyurgerov, M., Fastie, C., Griffith, B., Hollister, R., Hope, A., Huntington, H., Jensen, A., Jia, G., Jorgenson, T., Kane, D., Klein, D., Kofinas, G., Lynch, A., Lloyd, A., McGuire, A., Nelson, F., Oechel, W., Osterkamp, T., Racine, C., Romanovsky, V., Stone, R., Stow, D., Sturm, M., Tweedie, C., Vourlitis, G., Walker, M., Walker, D., Webber, P., Welker, J., Winker, K., and Yoshikawa, K., 2005, Evidence and implications of recent climate change in northern Alaska and other arctic regions: Climatic Change, v. 72, p. 251-298.

IPCC (Intergovernmental Panel on Climate Change), 2007, Climate change 2007 synthesis report, contribution of Working Groups I, II, and III to the fourth assessment report of the Intergovernmental Panel on Climate Change: IPCC, Geneva, Switzerland.

Jorgenson, M.T., Cater, T., Roth, J., Pullman, E., Racine, C., and Harden, J., 2007, Carbon accumulation in bogs and fens after permafrost degradation in central Alaska, in American Geophysical Union Fall Meeting, San Francisco, Dec. 10-14, 2007.

Jorgenson, T., Yoshikawa, K., Romanovsky, V., Kanevskiy, M., Brown, J., Shur, Y., Marchenko, S., Grosse, G., and Jones, B., 2008, Permafrost characteristics in Alaska, in Ninth International Conference on Permafrost (NICOP), Fairbanks, Alaska, June 30-July 4, 2008, extended abstracts: Fairbanks, Alaska, NICOP, p. 121.

Lillesand, T.M., Kiefer, R.W., and Chipman, J.W., 2008, Remote sensing and image interpretation: Hoboken, N.J., Wiley.

Schuur, E.A.G., Crummer, K.G., Vogel, J.G., and Mack, M.C., 2007, Plant species composition and productivity following permafrost thaw and thermokarst in Alaskan tundra: Ecosystems, v. 10, p. 280-292. 
Turetsky, M., Harden, J., McGuire, A., and Waddington, J., 2007, Ecohydrology controls on feedbacks between northern wetlands and climate systems, in American Geophysical Union Fall Meeting, San Francisco, Dec. 10-14, 2007.

Ulaby, F.T., DuBois, P.C., and Van Zyl, J., 1996, Radar mapping of surface soil moisture: Journal of Hydrology, v. 184, p. $57-84$.

Ulaby, F.T., Moore, R.K., and Fung, A.K., 1982, Microwave remote sensing active and passive, v. II-radar remote sensing and surface scattering and emission theory: Reading, Mass., Addison-Wesley, Advanced Book Program.

Wickland, K.P., and Neff, J.C., 2008, Decomposition of soil organic matter from boreal black spruce forest-environmental and chemical controls: Biogeochemistry, v. 87, p. $29-47$.

Wilson, E.H., and Sader, S.A., 2002, Detection of forest harvest type using multiple dates of Landsat TM imagery: Remote Sensing of Environment, v. 80, p. 385-396. 


\section{Appendix 1.}

Appendix 1. Individual European Remote Sensing satellite (ERS) SAR images used for interannual, multitemporal vertical send and vertical receive polarizations (VV), C-band SAR backscatter analysis of the Yukon Flats. All data ordered from and delivered by the Alaska Satellite Facility, University of Alaska Fairbanks.

\begin{tabular}{|c|c|c|c|c|}
\hline Date & Sensor & File /Granules & Band & Polarization \\
\hline 1993 & & ERS_1_1993.img & & \\
\hline May 12 & ERS-1 & E109535284G1S001 & $\mathrm{C}$ & VV \\
\hline June 16 & ERS-1 & E110036284G1S001 & $\mathrm{C}$ & VV \\
\hline July 21 & ERS-1 & E110537284G1S001 & $\mathrm{C}$ & VV \\
\hline August 25 & ERS-1 & E111038284G1S001 & $\mathrm{C}$ & VV \\
\hline September 29 & ERS-1 & E111539284G1S001 & $\mathrm{C}$ & VV \\
\hline 1997 & & ERS_1_1997.img & & \\
\hline July 22 & ERS-2 & E211792284G1S001 & $\mathrm{C}$ & VV \\
\hline August 7 & ERS-2 & E212021284G1S001 & $\mathrm{C}$ & VV \\
\hline September 11 & ERS-2 & E212522284G1S001 & $\mathrm{C}$ & VV \\
\hline October 16 & ERS-2 & E213023284G1S001 & $\mathrm{C}$ & VV \\
\hline November 20 & ERS-2 & E213524284G1S001 & $\mathrm{C}$ & VV \\
\hline 1998 & & ERS_1_1998.img & & \\
\hline March 5 & ERS-2 & E215027284G1S001 & $\mathrm{C}$ & VV \\
\hline April 9 & ERS-2 & E215757284G1S001 & $\mathrm{C}$ & VV \\
\hline May 14 & ERS-2 & E216029284G1S001 & $\mathrm{C}$ & $\mathrm{VV}$ \\
\hline June 18 & ERS-2 & E216759284G1S001 & $\mathrm{C}$ & $\mathrm{VV}$ \\
\hline July 23 & ERS-2 & E217031284G1S001 & $\mathrm{C}$ & VV \\
\hline August 27 & ERS-2 & E217532284G1S001 & $\mathrm{C}$ & VV \\
\hline October 1 & ERS-2 & E218033284G1S001 & $\mathrm{C}$ & VV \\
\hline 1999 & & ERS_2_1999.img & & \\
\hline May 15 & ERS-2 & E221268284G1S001 & $\mathrm{C}$ & VV \\
\hline June 19 & ERS-2 & E221769284G1S001 & $\mathrm{C}$ & VV \\
\hline July 24 & ERS-2 & E222270284G1S001 & $\mathrm{C}$ & VV \\
\hline August 28 & ERS-2 & E222771284G1S001 & $\mathrm{C}$ & VV \\
\hline October 2 & ERS-2 & E223272284G1S001 & $\mathrm{C}$ & VV \\
\hline 2004 & & ERS_2_2004.img & & \\
\hline May 8 & ERS-2 & E247320284G1S001 & $\mathrm{C}$ & VV \\
\hline June 12 & ERS-2 & E247821284G1S001 & $\mathrm{C}$ & VV \\
\hline
\end{tabular}


Appendix 1. Individual European Remote Sensing satellite (ERS) SAR images used for interannual, multitemporal vertical send and vertical receive polarizations (VV), C-band SAR backscatter analysis of the Yukon Flats. All data ordered from and delivered by the Alaska Satellite Facility, University of Alaska Fairbanks-Continued.

\begin{tabular}{|c|c|c|c|c|}
\hline Date & Sensor & File /Granules & Band & Polarization \\
\hline September 25 & ERS-2 & E249324284G1S001 & $\mathrm{C}$ & VV \\
\hline 2005 & & ERS_2_2005.img & & \\
\hline July 2 & ERS-2 & E253332284G1S001 & $\mathrm{C}$ & VV \\
\hline August 6 & ERS-2 & E253833284G1S001 & $\mathrm{C}$ & VV \\
\hline 2006 & & ERS_2_2006.img & & \\
\hline October 3 & ERS-2 & E259888284G1S001 & $\mathrm{C}$ & VV \\
\hline 2007 & & ERS_2_2007.img & & \\
\hline May 1 & ERS-2 & E262894284G1S001 & $\mathrm{C}$ & VV \\
\hline June 5 & ERS-2 & E263395284G1S001 & $\mathrm{C}$ & VV \\
\hline July 10 & ERS-2 & E263896284G1S001 & $\mathrm{C}$ & VV \\
\hline August 14 & ERS-2 & E264397284G1S001 & $\mathrm{C}$ & VV \\
\hline September 18 & ERS-2 & E264898284G1S001 & $\mathrm{C}$ & VV \\
\hline
\end{tabular}




\section{Appendix 2.}

Appendix 2. Individual SAR images used for multitemporal, Japanese Earth Resources Satellite (JERS), L-band SAR backscatter analysis of the Yukon Flats with horziontal polarizations for sending and receiving (HH). All data originated from the Alaska Satellite Facility, University of Alaska Fairbanks.

\begin{tabular}{lllll}
\hline \multicolumn{1}{c}{ Date } & Sensor & & Band & Polarization \\
\hline August 30 & & 1993 & & \\
\hline & JERS & & L & HH \\
\hline October 17 & & 1996 & & \\
\hline & JERS & & L & HH \\
\hline February 26 & & 1997 & & HH \\
April 11 & JERS & & L & HH \\
May 25 & JERS & & L & HH \\
July 8 & JERS & & L & HH \\
August 21 & JERS & & L & HH \\
November 17 & JERS & & L & HH \\
December 31 & JERS & & L & HH \\
\hline & JERS & & L & \\
\hline February 13 & & & HH \\
March 29 & JERS & & L & HH \\
May 12 & JERS & & L & HH \\
June 25 & JERS & L & HH \\
September 21 & JERS & L & HH \\
\hline & JERS & L &
\end{tabular}


Publishing support provided by

Rolla and Lafayette Publishing Service Centers

For more information concerning this publication, contact:

U.S. Geological Survey Earth Resources Observation and Science (EROS) Center Sioux Falls, South Dakota

(605) 594-6151

Or visit the EROS Center Web site at:

World Wide Web: http://eros.usgs.gov/ 
